\title{
The Increase of Drop Out Rate on Contraceptives Usage in Central Sulawesi (Raw Data Analysis of 2017 Indonesian Demographic and Health Survey (IDHS))
}

\author{
Surayya $^{1}$, Dyah Fitria Kartika Sari ${ }^{2 *}$, Budiman Jaya ${ }^{3}$ \\ ${ }^{I}$ Department of Management Studies, Faculty of Economics and Business, Tadulako University \\ ${ }^{2}$ Department of Communication Studies, Faculty of Social and Political Sciences, Tadulako University \\ ${ }^{3}$ National Agency of Population and Family Planning (BKKBN) Regional Office of Central Sulawesi \\ *dyahfitriakartika@gmail.com
}

\begin{abstract}
This study discusses the increase of drop out rate on contraceptives usage and its various underlying factors in the use of family planning in Central Sulawesi as one of many phenomena that occurs in the community. Therefore, this study describes the phenomenon of family planning drop outs in Central Sulawesi to illustrate how the increase of drop out rate on contraceptive usage affects National Agency of Population and Family Planning Regional Office of Central Sulawesi in policy and decisions making. Logistic regression results of 2017 Indonesian Demographic and Health Survey on contraceptives usage data showed that injection had the highest drop out rate (31.9\%), followed by Pills (11.9\%), coitus interruptus (4\%), and implant (2.4\%). Some contraceptives methods that had below $2 \%$ drop out rate are periodic abstinence (1.8\%), male condoms (1.3\%), IUD (1\%), LAM method $(0.5 \%)$ and other traditional methods $(0.3 \%)$. The high drop out rate of contraceptive usage will affect the continuity of the Family Planning program.
\end{abstract}

Keywords: Contraceptives Usage, Drop Out Rate, Family Planning Program, IDHS 


\section{STRADA Jurnal Ilmiah Kesehatan}

DOI: $10.30994 /$ sjik.v9i2.282

ISSN: 2252-3847 (print); 2614-350X (online)

Vol.9 No.2 November 2020 Page.1495-1503

\section{BACKGROUND}

Birth Control based Family Planning (Keluarga Berencana, abbreviated as KB) is a program launched by the Indonesian government to reduce the surge in population. The birth rate is increasing annually. Thus, the Family Planning program plays an integral part in the sustainability and welfare of the Indonesian population. Projected data from the National Development Planning Agency (Bappenas) in 2013 showed that the population will reach 265 million in 2018. The number consisted of 133.17 million men and 131.88 million women. According to age groups, the total population consists of 70.49 million (26.6\%) children (0-14 years old), 179.13 million (67.6\%) productive age category (14-64 years old) and 85.89 million (5.8\%) elderlies (65 years old and over). From this projection, the fertility/birth rate reached 4.81 million while the deaths/mortality rate was 1.72 million. The ratio of dependency rate (productive age to non-productive age) was $47.9 \%$ which was lower than the previous year (48.1\%) and 2010 which reached 50.5\% (Katadata, 2018).

The Family Planning program itself is a program launched by the government for couples who are married at childbearing age. Households of childbearing age must have planned in terms of reproduction and family survival. The Family Planning program itself helps to regulate birth spacing, reducing the risk of births and deaths during pregnancy and childbirth. Also, the Family Planning program can regulate economic planning and family welfare. Realizing the Family Planning program is the responsibility of all Indonesians, including the people of Central Sulawesi. Users of contraception should be safeguarded, but field data states that there is a discontinuation of the use of contraception.

The success of the Family Planning program launched by the government does not only become the responsibility of one party but also all elements in society. If the discontinuation of contraceptive devices continues and is not handled properly, the snowball effect will ensue. Based on data presented by Sudibyo, the Deputy of Family Welfare and Family Empowerment of National Agency of Population and Family Planning, the drop out rate of Family Planning participants in Indonesia is still quite high where $27 \%$ of contraceptive users stop using their contraception after a year of use (Berita Satu, 2013).

The objectives of the next five years are to rebuild and preserve a solid foundation for implementing a strong Family Planning program in the future to realize the vision of a quality family in 2010 (Arum \& Sujiyatini, 2009, p. 28). Thus, philosophically, the objectives of the Family Planning program (Handayani, 2010), are:

a. To improve the welfare and creating a happy and prosperous small family through birth and population growth control in Indonesia;

b. The creation of quality residents and human resources.

The targets of the Family Planning program are divided into direct and indirect targets, depending on the objectives. The immediate target is Fertile/Childbearing Age Couples which targeted to reduce birth rates by using contraception on an ongoing basis (Bitew \& Nyarko, 2019; Jerman et al., 2019). While the indirect target is Family Planning implementers and managers which aimed to reduce birth rates through an integrated population policy approach to achieve a quality and prosperous family (Handayani, 2010, p. 29).

The implementation of the Family Planning program has decreased since the early 2000s when the decentralization policy was implemented. Regional Family Planning Management Institutions began to be integrated with other institutions replacing the National Agency of Population and Family Planning Regional Offices. Some regions consider the Family Planning program is not important based on the assessment of land 


\section{STRADA Jurnal Ilmiah Kesehatan}

DOI: $10.30994 /$ sjik.v9i2.282

ISSN: 2252-3847 (print); 2614-350X (online)

Vol.9 No.2 November 2020 Page.1495-1503

areas and population ratio. For regional expansion reasons, several regions have instead sought to increase the population to meet the requirements for the formation of regencies or cities. This reflects a decrease in the priority of Family Planning programs in regional governments level.

\section{METHODS}

Quantitative data is used in this study based on the fact that quantitative data is a type of data that can be measured and calculated directly. The data used in this research are collected using a literature study on the 2017 Indonesian Demographic and Health Survey (IDHS) data. The data analysis technique used is logistic regression where the Central Sulawesi IDHS data on the drop out of the use of contraception in Central Sulawesi are examined.

Inferential statistical analysis used in this study is the logistic regression analysis. The use of logistic regression analysis is based on the dummy dependent variable (accepting or not receiving the opinion of ongoing concern). Logistic regression is almost the same as the discriminant analysis, which is used to test whether the probability of the occurrence of the dependent variable can be predicted by the independent variable (Ghozali, 2016, p. 333). Logistic hypothesis testing (logistic regression) is used if the independent variable is a combination of metric and non-metric (nominal). The logistic regression analysis technique no longer requires a normality test and a classic assumption test on the independent variable (Ghozali, 2016, p. 333). The data is analyzed and described as a form of the results of decisions that will be made as a form of policy determinant in the provision of Family Planning to the community, especially in Central Sulawesi Province.

\section{RESULTS}

The results of the study are based on 2017 IDHS raw data on the drop out rate of Family Planning in Central Sulawesi. Based on the results of the 2017 IDHS data after being processed using logistic regression analysis, the number of samples in Central Sulawesi was 537 people. This sample is scattered in all regencies and cities in Central Sulawesi Province. The sample is used as a reference to measure the results of the 2017 IDHS data on the drop out of the contraceptive method in Central Sulawesi.

Table 1. Research Sample Based on 2017 IDHS Data

\begin{tabular}{|c|r|r|r|c|}
\hline \multicolumn{5}{|c|}{ V024=72 (FILTER) } \\
\hline & $\begin{array}{c}\text { Frequenc } \\
\text { y }\end{array}$ & Percent & $\begin{array}{c}\text { Valid } \\
\text { Percent }\end{array}$ & $\begin{array}{c}\text { Cumulative } \\
\text { Percent }\end{array}$ \\
\hline Valid Selected & 537 & 100,0 & 100,0 & 100,0 \\
\hline
\end{tabular}

Source: 2017 IDHS Data, 2019

The results of the logistic regression projected 537 samples which scattered in all cities and regencies in Central Sulawesi Province. Aforementioned 537 samples were used as a reference to measure the results of the 2017 IDHS data on the drop out of contraceptive usage in Central Sulawesi. 


\section{STRADA Jurnal Ilmiah Kesehatan}

DOI: $10.30994 /$ sjik.v9i2.282

ISSN: 2252-3847 (print); 2614-350X (online)

Vol.9 No.2 November 2020 Page.1495-1503

\begin{tabular}{clc}
\multicolumn{3}{c}{ Table 2. Contraceptive Usage Based on Methods } \\
No. & Contraceptive Method & Percentage \\
1 & Traditional method & 8,2 \\
2 & Modern method & 91,8 \\
Total & & $\mathbf{1 0 0 , 0}$
\end{tabular}

Source: 2017 IDHS Data, 2019

$8.2 \%$ of the population still uses traditional methods to regulate the birth rate. These traditional methods for examples are by-calendar periodic abstinence method and coitus interuptus. While $91.8 \%$ has used the modern methods of contraception. Modern contraceptive methods are considered more practical and effective although there are costs involved. Some of the modern methods used by the people of Central Sulawesi are injection, male condoms, sterilization for both men and women, implants, IUDs and pills. Based on the use of the contraceptive method for five years before the 2017 IDHS sampling conducted, several types of contraceptive methods were used by both women and men in Central Sulawesi.

$\begin{array}{clc}\begin{array}{c}\text { Table } \\ \text { No }\end{array} & \text { 3. Contraceptives Usage Based on } 2017 \text { IDHS Data } \\ \text { Contraceptive Types } & \begin{array}{c}\text { Percentages } \\ 1\end{array} \text { Pill } & 1,2 \\ 2 & \text { IUD } & 1,2 \\ 3 & \text { Injections } & 2,1 \\ 4 & \text { Male condom } & 1,8 \\ 5 & \text { Female sterilization } & 3,0 \\ 6 & \text { Male sterilization } & 0,1 \\ 7 & \text { Periodic abstinence } & 2,2 \\ 8 & \text { Withdrawal/coitus interuptus } & 5,6 \\ 9 & \text { Other traditional } & 0,4 \\ 10 & \text { Implants/Norplant } & 8,6 \\ 11 & \text { Lactational amenorrhea (LAM) } & 0,6 \\ 12 & \text { Other modern method } & 0,0 \\ 13 & \text { Specific method 1 } & 73,2 \\ \text { Total } & & \mathbf{1 0 0 , 0}\end{array}$

Source: 2017 IDHS Data, 2019

The results of the 2017 IDHS data above illustrate the use of various contraceptives methods used by the people in Central Sulawesi. From a total sample of 537, only $0.1 \%$ of users use male sterilization. This method has the lowest percentage of use compared to other methods. Some methods where the percentage is below one per cent are other traditional methods $(0.4 \%)$. Also, the LAM method is only used by $0.6 \%$ of the total of 537 samples. The data on the use of contraceptive methods above also illustrates that the special method (Specific Method 1) is the most widely used in Family Planning with $73.2 \%$ of the total 537 samples. Some methods that are also quite widely used are implants. This method is done by inserting implants into the body where usually this method is done by cutting the surface of the user's skin (Che et al., 2019). A total of 8.6\% of the sample chose the implant/Norplant method of contraception. One method of contraception that is more than one per cent is withdrawal or external sperm excretion 


\section{STRADA Jurnal Ilmiah Kesehatan}

DOI: $10.30994 /$ sjik.v9i2.282

ISSN: 2252-3847 (print); 2614-350X (online)

Vol.9 No.2 November 2020 Page.1495-1503

(5.6\%) which is considered to be relatively safe and relatively cheap/cost-free. Next is female sterilization method which is amounting to $3 \%$ out of 537 samples.

$1.2 \%$ of correspondents chose to use birth control pills, as well as the selection of IUDs which reached $1.2 \%$ of the total sample. The male condom is one of the people's choices as a method of contraception and as many as $1.8 \%$ chose this method as a method that is considered effective in preventing pregnancy. One of the usual and often chosen methods for women in Family Planning is the injection method $(2.1 \%)$ which is considered as an effective and easy method of contraception.

$\begin{array}{clc}\begin{array}{c}\text { Table } \\ \text { No }\end{array} & \begin{array}{c}\text { Contraceptives Usage Drop Out Rate in } 5 \text { Years } \\ \text { Contraceptive Types }\end{array} & \begin{array}{c}\text { Persentase } \\ 11,9\end{array} \\ 1 & \text { Pill } & 1,0 \\ 2 & \text { IUD } & 31,9 \\ 3 & \text { Injections } & 1,3 \\ 4 & \text { Male condom } & 1,8 \\ 5 & \text { Female sterilization } & 4,0 \\ 6 & \text { Male sterilization } & 0,3 \\ 7 & \text { Periodic abstinence } & 2,4 \\ 8 & \text { Withdrawal/coitus interuptus } & 0,5 \\ 9 & \text { Other traditional } & 55,2 \\ 10 & \text { Implants/Norplant } & 11,9 \\ 11 & \text { Lactational amenorrhea (LAM) } & 1,0 \\ 12 & \text { Other modern method } & 31,9 \\ 13 & \text { Specific method 1 } & \mathbf{1 0 0 , 0} \\ \text { Total } & & \end{array}$

The 2017 IDHS data showed that injection was the highest number of drop outs which was amounting to $31.9 \%$. In addition to the injection method, the contraceptive pill was one of the methods with the highest drop out number (11.9\%). Around $4 \%$ of drop out were also seen on coitus interuptus or withdrawal methods. Even though this method is simple, easy and relatively cheap/cost-free, it turns out there were $4 \%$ acceptors who chose not to use it anymore. Some reasons may be used as factors in terminating the use of this method.

Next is contraception by implants where the 2017 IDHS data shows $2.4 \%$ decided to stop or drop out. The discontinuation of the implant-based contraceptive method can be motivated by several things, one of which is the incurred cost. This is because the process of using the contraceptive device is done by implanting both the womb and the female arm. The use of this contraceptive method is considered a bit risky because it corresponded with the little surgery to be applied. The next alternative to using contraception is periodic abstinence. IDHS data shows that around $1.8 \%$ of periodic abstinence users chose to drop out. Periodic abstinence is a simple method because it only refers to the calendar by looking at a woman's fertile period but the low accuracy of this method in calculating a woman's fertile period is affecting the users to drop out.

The next alternative based on IDHS data is male condoms. The results of the IDHS data show that out of the 537 samples, around $1.3 \%$ chose not to use or drop out using condoms. Also, as much as $1 \%$ of IUD users and $0.5 \%$ of LAM method users chose to 


\section{STRADA Jurnal Ilmiah Kesehatan}

DOI: $10.30994 /$ sjik.v9i2.282

ISSN: 2252-3847 (print); 2614-350X (online)

Vol.9 No.2 November 2020 Page.1495-1503

drop out. In addition to the previously mentioned methods, there is also $0.3 \%$ drop-out on other traditional methods.

\section{DISCUSSIONS}

Contraception is a method and tool used to regulate the number, rate and spacing of births in the family (Siswosudarmo et al., 2007). Contraception is important to do because family welfare will also be influenced by the number of dependents in the family. Welfare itself is not only material but also in social life and how to educate and care for children (Saifuddin, 2006). Contraception itself is a way to prevent conception (Choi et al., 2019; Mufdlilah \& Aryekti, 2016). Contraception method can also be permanent. Contraception that is considered ideal should be $100 \%$ effective, very safe, painless and reversible. Contraception should not interfere with spontaneity, do not pollute, do not smell and should not give strong sensation. Also, contraceptives must be easy to use, inexpensive, does not depend on the user's memory, and does not depend on health workers. The method used also should not contrary to local culture, thus it can be accepted by its users. One of the considerations for contraception today is protection from sexually transmitted infections, but such contraception is not yet available.

The use of contraception is not side effects free. A user of a contraceptive method has its consideration in choosing the method of its use. From the data explained on research results, Specific Method 1 is the most widely used in Family Planning, amounting to $73.2 \%$ of the total 537 samples. Specific Method 1 is different in each country. In Indonesia, Specific Method 1 is included in the special method of contraception performed by women of childbearing age who do the injection method for three months. From the analysis of the 2017 IDHS data, Specific Method 1 is the method with the highest percentage of use compared to other methods of contraception.

Choosing to use a contraceptive method is the same as accepting the consequences and effects of the contraceptive method itself. An important factor in the effort of the Family Planning program is the selection of appropriate contraception (Septalia \& Puspitasari, 2016). The choice of contraception based on its effectiveness is categorized into two choices. injections, pills, and condoms are included in non-long-term contraceptive methods category and IUD, implant, MOW, and MOP are included in longterm contraceptive methods category. The method of contraception itself is inseparable from the risks posed. Each method chosen has an effect and limitation in its use (Ponce de Leon et al., 2019; Steiner et al., 2019). Thus, it is not uncommon for people who have chosen the method of contraception and finally stopped using it with a variety of affecting factors.

The phenomenon of discontinuing the use of the contraceptive method or drop out is an event where the user stops using one or all of the contraceptive methods. Various considerations and factors could support the decision to drop out. Where both women or men who use contraceptive methods decide not to use it at all or choose to try other methods for various reasons. Knowledge is one of the elements needed in thought patterns and behaviour which affect the drop out. Knowledge about the contraception type, advantages and disadvantages will influence someone to choose the appropriate type of contraception. By having good knowledge regarding Family Planning, women of couples of childbearing age will certainly have a positive attitude towards contraception which directly related to reproductive health.

Family Planning Program drop out could be affected by many factors and is not limited to certain regions and province, thus the drop out also happens in Central Sulawesi. 


\section{STRADA Jurnal Ilmiah Kesehatan}

DOI: $10.30994 /$ sjik.v9i2.282

ISSN: 2252-3847 (print); 2614-350X (online)

Vol.9 No.2 November 2020 Page.1495-1503

2017 IDHS data analysis explained in the research results shows the discontinuations number which is an injection (31.9\%). $4.5 \%$ of women decided to discontinue the use of contraceptive devices because they wanted to get pregnant, $4.7 \%$ per cent decided not to use these contraceptives and chose other contraceptive devices/methods because of high enough risk (the emergence of abnormal bleeding in women, does not protect from infectious diseases, weight gain/obesity and decreased sex drive).

One method of contraception that dropped out is the contraceptive pills. As an easy method of contraception, this method is also relatively costly based on required daily use. The cost can be one of the factors that influence the drop out and can affect the range of contraceptive use in Family Planning (Septalia \& Puspitasari, 2016). The logistic regression test results show that the cost has a significant effect on the choice of contraceptive methods.

Costs and sources of services show a significant correlation with Family Planning demand (Pastuti \& Wilopo, 2007). Access to services is related to the availability of service personnel, facilities and reproductive health commodities, financing and purchasing power parity. Respondents who use government facilities have a higher chance of limiting births. Conversely, if there are no costs incurred or getting a free Family Planning request, the opportunity to limit births is higher.

The overall use of contraceptive methods has increased significantly as illustrated in the results of 2017 IDHS data. 2017 IDHS data shows that as many as $19.5 \%$ of the community decided to use the contraceptive method in 2015 and continued to increase in 2016 with a significant percentage amount of $28.6 \%$. However, in 2017 the increase was only $0.3 \%$. This is clearly illustrated not only that the public awareness to be a Family Planning acceptor has increased annually but a few also do drop out.

The large percentage of drop out could be due to side effects caused by contraception (Kavoussi et al., 2017). The higher the incompatibility of contraceptive use (experiencing side effects) the higher the drop-out method for birth control methods. This factor can be used as a reason for the high drop out phenomenon that occurs in Central Sulawesi in addition to external factors such as lack of knowledge of Family Planning acceptors on the contraceptive method used. Not all acceptors in Central Sulawesi are in urban areas. Thus, the obtained information is not as much and as good as those living in cities with good access to information.

The results of the IDHS data show that out of 537 studied samples, around $1.3 \%$ of the people of Central Sulawesi Province no longer choose to use using condoms. Other contraceptive methods also dropped out of their use, namely the IUD (1\%) and LAM method $(0.5 \%)$. Also, other traditional methods had $0.3 \%$ acceptor drop out data. The drop out phenomenon had many factors influencing it which can also be used as a reason for the lack of drop out (Aini et al., 2006). For example, the acceptors are judging that the contraceptive methods are suitable and feel comfortable thus making the percentage of drop out to be small. Also, another factor that also affects the small percentage of drop out is the lack of acceptors who choose this particular method.

Looking at the results of the processed 2017 IDHS secondary data, as much as $8.2 \%$ of the community uses traditional methods to regulate the birth rate. These traditional methods themselves include by-calendar periodic abstinence method, coitus interruptus and so forth. While $91.8 \%$ of people have used modern contraception methods. Modern contraception has a lower overall percentage of drop outs, although there are several modern methods of contraception with a high drop out percentage on its own. In general, it can be described that modern methods of contraception acceptors who choose to drop out 


\section{STRADA Jurnal Ilmiah Kesehatan}

DOI: $10.30994 /$ sjik.v9i2.282

ISSN: 2252-3847 (print); 2614-350X (online)

Vol.9 No.2 November 2020 Page.1495-1503

for various reasons tend to exceed $1 \%$. Although the percentage of some modern contraception acceptors dropping out is still relatively high, modern contraception has still many interests, is easy and practical to use (Ahmed et al., 2019; Bitew \& Nyarko, 2019). Thus, modern contraception becomes one of the more suitable choices of contraceptive methods.

\section{CONCLUSION}

The drop out phenomenon in Central Sulawesi, based on 2017 IDHS data, illustrates that the highest number of drop-outs is a contraceptive injection (31.9\%). In addition to the injection method, the contraceptive pill drop out rate is $11.9 \%$. The third highest contraception method drop out rate is coitus interruptus at $4 \%$. About $2.4 \%$ of contraceptive implant users decide to stop or drop out of using the implant method. Next is periodic abstinence users with $1.8 \%$ drop out rate. The male condom drop out rate in Central Sulawesi is around $1.3 \%$. While another contraceptive method dropped out of use is the IUD (1\%) and the LAM method $(0.5 \%)$. In addition to the previously mentioned methods, other traditional methods also obtained $0.3 \%$ drop-out rate.

Some factors that could affect the drop out phenomenon include, among others, the lack of information received by acceptors, the contraceptive method failure rate, the side effects caused by each contraceptive method and other external factors.

\section{REFERENCES}

Ahmed, S., Choi, Y., Rimon, J. G., Alzouma, S., Gichangi, P., Guiella, G., Kayembe, P., Kibira, S. P., Makumbi, F., OlaOlorun, F., Omoluabi, E., Otupiri, E., Oumarou, S., Seme, A., Shiferaw, S., Anglewicz, P., Radloff, S., \& Tsui, A. (2019). Trends in contraceptive prevalence rates in sub-Saharan Africa since the 2012 London Summit on Family Planning: results from repeated cross-sectional surveys. The Lancet Global Health, 7(7), e904-e911. https://doi.org/10.1016/S2214-109X(19)30200-1

Aini, A., Mawarni, A., \& Dharminto, D. (2006). Faktor-Faktor Yang Berhubungan Dengan Kejadian Drop Oout Akseptor KB Di Kecamatan Tembalang Kota Semarang. Jurnal Kesehatan Masyarakat (e-Journal), 4(4), 169-176. https://ejournal3.undip.ac.id/index.php/jkm/article/view/13985

Arum, D., \& Sujiyatini. (2009). Panduan Lengkap Pelayanan KB Terkini. Nuha Medika.

Berita Satu. (2013). BKKBN: Tingkat "Drop Out" KB di Indonesia Masih Tinggi. Beritasatu.Com. https://www.beritasatu.com/kesehatan/140849/bkkbn-tingkat-dropout-kb-di-indonesia - masih -tinggi

Bitew, F., \& Nyarko, S. H. (2019). Modern contraceptive use and intention to use: implication for under-five mortality in Ethiopia. Heliyon, 5(8), e02295. https://doi.org/10.1016/j.heliyon.2019.e02295

Che, Y., Taylor, D., Luo, D., Maldonado, L., Wang, M., Wevill, S., Vahdat, H., Han, X., Halpern, V., Dorflinger, L., \& Steiner, M. (2019). Cohort study to evaluate efficacy, safety and acceptability of a two-rod contraceptive implant during third, fourth and fifth year of product use in China. Contraception: X, 1, 100008. https://doi.org/10.1016/j.conx.2019.100008

Choi, Y., Khanna, A., Zimmerman, L., Radloff, S., Zachary, B., \& Ahmad, D. (2019). Reporting sterilization as a current contraceptive method among sterilized women: lessons learned from a population with high sterilization rates, Rajasthan, India. Contraception, 99(2), 131-136. https://doi.org/10.1016/j.contraception.2018.10.006 


\section{STRADA Jurnal Ilmiah Kesehatan}

DOI: $10.30994 /$ sjik.v9i2.282

ISSN: 2252-3847 (print); 2614-350X (online)

Vol.9 No.2 November 2020 Page.1495-1503

Ghozali, I. (2016). Aplikasi Analisis Multivariate dengan Program IBM SPSS 21 (7th ed.). Badan Penerbit Universitas Diponegoro.

Handayani, S. (2010). Buku Ajar Pelayanan Keluarga Berencana. Pustaka Rihama.

Jerman, J., Berry, A., \& Kavanaugh, M. L. (2019). Challenges and strategies for contraceptive care in independent abortion clinics in the United States, 2017. Sexual \& Reproductive Healthcare, 21, 102-107. https://doi.org/10.1016/j.srhc.2019.07.001

Katadata. (2018). Jumlah Penduduk Indonesia Mencapai 265 Juta Jiwa. Katadata.Co.Id. https://databoks.katadata.co.id/datapublish/2018/05/18/2018-jumlah-pendudukindonesia-mencapai-265-juta-jiwa

Kavoussi, S. K., Odenwald, K. C., As-Sanie, S., \& Lebovic, D. I. (2017). Incidence of ovarian endometrioma among women with peritoneal endometriosis with and without a history of hormonal contraceptive use. European Journal of Obstetrics \& Gynecology and Reproductive Biology, 215, 220-223. https://doi.org/10.1016/j.ejogrb.2017.06.028

Mufdlilah, M., \& Aryekti, K. (2016). DUKUNGAN SUAMI TERHADAP KEJADIAN DROP OUT BAGI AKSEPTOR KELUARGA BERENCANA (KB) DI DESA DAN KOTA DI DAERAH ISTIMEWA YOGYAKARTA. Musãwa Jurnal Studi Gender Dan Islam, 15(1), 113-124. https://doi.org/10.14421/musawa.2016.151.113-124

Pastuti, R., \& Wilopo, S. A. (2007). Determinan Penggunaan Metode Kontrasepsi IUD di Indonesia Analisis Data SDKI 2002-2003. Berita Kedokteran Masyarakat, 23(2), 7180. https://doi.org/https://doi.org/10.22146/bkm.3627

Ponce de Leon, R. G., Ewerling, F., Serruya, S. J., Silveira, M. F., Sanhueza, A., Moazzam, A., Becerra-Posada, F., Coll, C. V. N., Hellwig, F., Victora, C. G., \& Barros, A. J. D. (2019). Contraceptive use in Latin America and the Caribbean with a focus on long-acting reversible contraceptives: prevalence and inequalities in 23 countries. The Lancet Global Health, 7(2), e227-e235. https://doi.org/10.1016/S2214109X(18)30481-9

Saifuddin, A. B. (2006). Buku Panduan Praktis Pelayanan Kesehatan Maternal dan Neonatal. Yayasan Bina Sarwono Prawirohardjo.

Septalia, R., \& Puspitasari, N. (2016). Faktor yang Memengaruhi Pemilihan Metode Kontrasepsi. Jurnal Biometrika Dan Kependudukan, 5(2), 91. https://doi.org/10.20473/jbk.v5i2.2016.91-98

Siswosudarmo, H. R., Anwar, H. M., \& Emilia, O. (2007). Teknologi Kontrasepsi. Gadjah Mada University Press.

Steiner, M. J., Brache, V., Taylor, D., Callahan, R., Halpern, V., Jorge, A., Wevill, S., Sergison, J., Venkatasubramanian, L., \& Dorflinger, L. (2019). Randomized trial to evaluate contraceptive efficacy, safety and acceptability of a two-rod contraceptive implant over 4 years in the Dominican Republic. Contraception: X, 1, 100006. https://doi.org/10.1016/j.conx.2019.100006 